Molecules 2006, 11, 121-129

molecules

ISSN 1420-3049

http://www.mdpi.org

\title{
Synthetic Studies on Erythromycin Derivatives: Reactivity of the C12-21 Alkene
}

\author{
Wei-Min Chen \\ Department of Medicinal Chemistry, School of Pharmacy, Jinan University, Guangzhou, 510632, P.R. \\ China; E-mail: twmchen@jnu.edu.cn
}

Received: 8 January 2006 / Accepted: 23 January 2006 / Published: 31 January 2006

\begin{abstract}
The reactivity of the C12-21 alkene of some erythromycin A derivatives was studied. This double bond was easily oxidized to the corresponding epoxide with excellent stereoselectivity. A single crystal X-ray structure showed that the epoxide moiety was on the same side as the acetonide. When an erythromycin derivative containing a C12-21 alkene was treated with diazomethane a [3+2] cycloaddition affording a pyrazoline occurred. In the case of 6-O-allylated erythromycin derivatives the C12-21 alkene was selectively epoxidized in the presence of the 6-O-allyl moiety. These results show that the $\mathrm{C} 12-21$ alkene is an active reaction site, which can be used for useful further modification of erythromycin derivatives.
\end{abstract}

Keywords: Erythromycin, alkene, epoxidation, cycloaddition, pyrazoline.

\section{Introduction}

Erythromycin A (1, Figure 1) is one of the most successful antibiotics ever discovered, and has been used for the treatment of bacterial infections over the past 50 years. Despite its popularity, however, erythromycin suffers from several problems associated with its use. First, erythromycin is not effective against most aerobic enteric gram-negative bacilli. Secondly, erythromycin is metabolized by liver enzymes, competing with other drugs such as theophylline and common hay fever remedies, leading to overdoses of these drugs. Finally, erythromycin is not very stable below $\mathrm{pH}$ 6.9, making formulation somewhat difficult. To overcome these problems and drug resistance, many erythromycin derivatives have been synthesized $[1,2]$. Among the modifications examined is the elimination of the 12-OH group, resulting in new analogues with a C12-21 double bond such as 2 [2, 
3]. The C12-21 double bond has been osmylated to provide a diol, hydroborated to a primary alcohol or epoxidized. The epoxide was opened with an amine [4] or other compounds, thereby introducing basic and polar functionalities at the $\mathrm{C}-21$ position. We have previously reported erythromycin derivatives with modifications at the C12-21 alkene [5]. We report herein the design and synthesis of new erythromycin intermediates with modifications at the C12-21 alkene. These compounds can be used as starting materials to make a variety of new erythromycin derivatives.

Figure 1. Structures of erythromycin A and its C12-21 alkene analogue

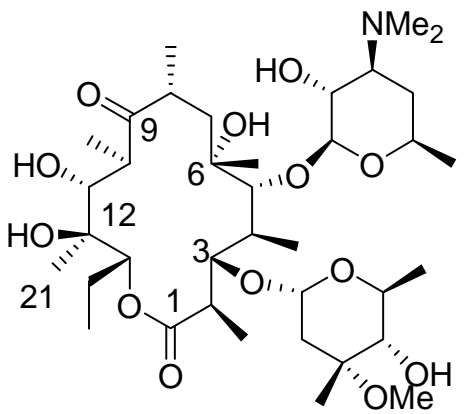

Erythromycin A, 1

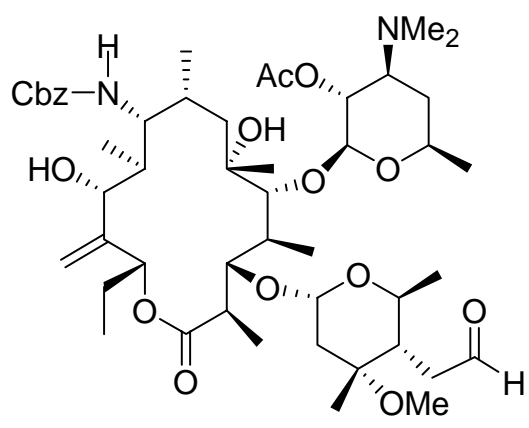

2

\section{Results and Discussion}

The epoxidation of (9S)-9,11-O-isopropylidene-2',4'-O-bis(benzoyl)-12,21-anhydro-9-dihydroerythromycin A (3).

It is known that the alkene moiety is easily oxidized to generate an epoxide, which can then be converted into other useful structures, such as a diol. For this reason, compound 3, prepared as previously reported [5], was oxidized by treatment with $m$-chloroperbenzoic acid ( $m$-CPBA, Scheme 1). As expected, not only the C12-21 double bond but also the tertiary amine was oxidized, affording compound 4 . The $\mathrm{N}$-oxide $\mathbf{4}$ was then reduced by treatment with sodium sulfite to afford epoxide $\mathbf{5}$ in good yield (69\%).

Scheme 1. Epoxidation of the C12-21 double bond

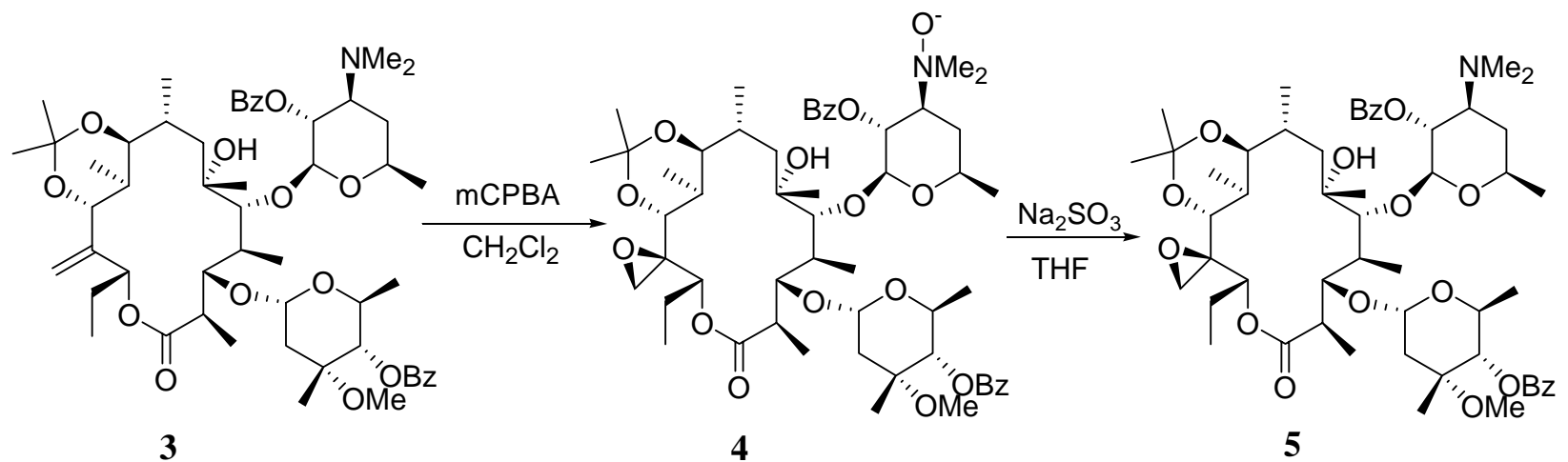


The stereospecificity of the C12-21 epoxidation reaction was confirmed by a single crystal X-ray structure study. The epoxide was found on the upper side of the molecule and with $\mathrm{C}-12 R$ conformation (Figure 2). It should be very interesting to find out whether compounds with different configurations at this position have different activity.

Figure 2. Crystal structure of compound 5

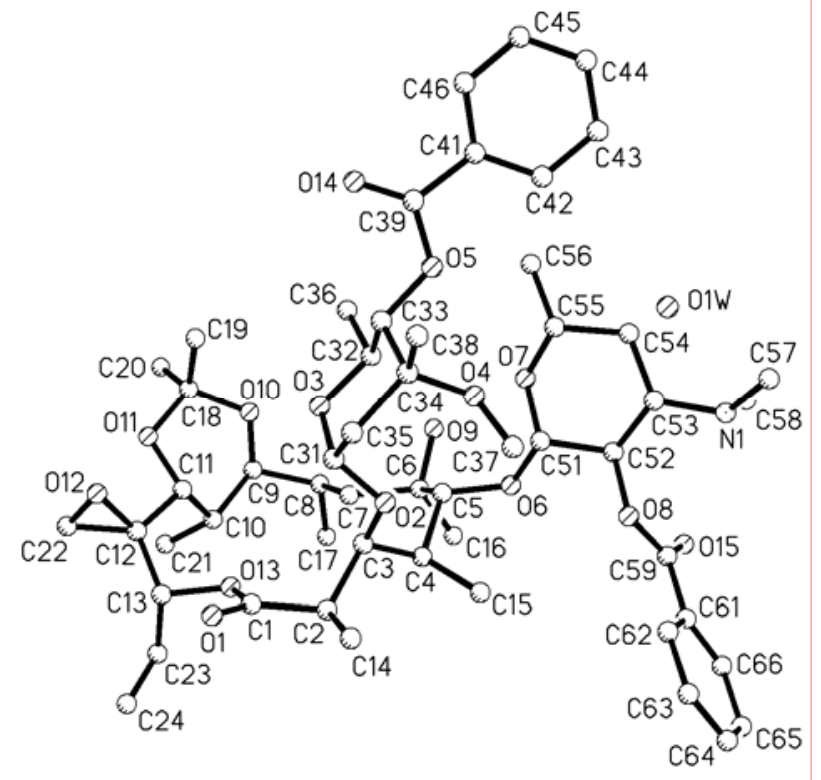

[3+2] Cycloaddition of the C12-21 alkene with diazomethane.

The diazo moiety is another versatile chemical moiety that can be easily converted into other groups. Thus, compound 3 was treated with diazomethane, affording the 1,3-dipolar cycloaddition product 6 (Scheme 2). NMR spectral analysis of compound 6 demonstrated that the regiochemical preference of the electron-withdrawing substitutent is toward to the $N$-portion of the dipole [6,7], affording a C-12- $\Delta^{1}$-pyrazoline derivative. Since pyrazoline derivatives have been demonstrated to possess many different biologically activities [8,9], compound $\mathbf{6}$ might be an intermediate from which active antibiotics could be made.

Scheme 2. Conversion of the C12-21 double bond to a pyrazoline moiety

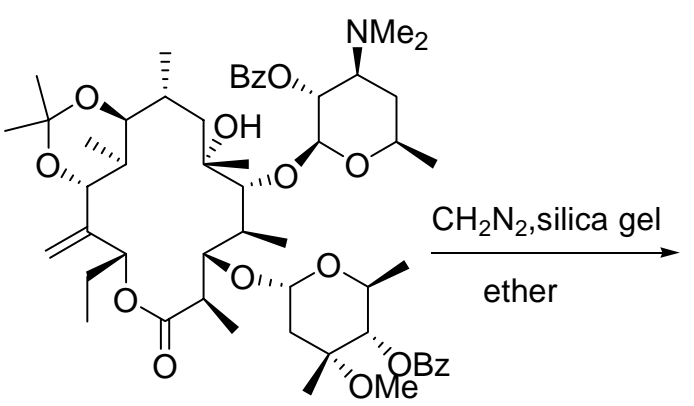

3

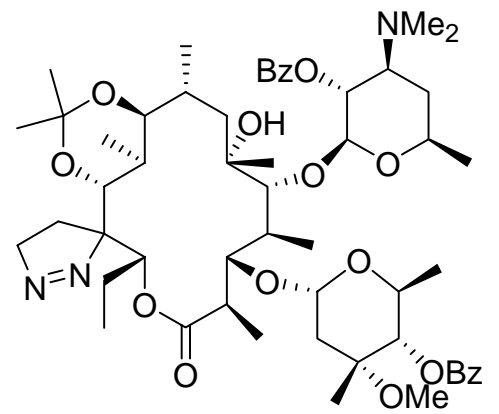

6 
Epoxidation of erythromycin derivatives containing two alkene groups.

To obtain more versatile erythromycin intermediates, two double bonds were introduced into compound 3. An allylic group was added to the $6-\mathrm{OH}$ of compound 3 by treatment with allyl methyl carbonate in the presence of palladium acetate (Scheme 3) [10], affording compound 7. The latter was then treated with $m$-CPBA. Surprisingly, the 6-allylic group was not affected during the reaction and only the C12-21 double was oxidized, affording compound $\mathbf{8}$. Another side product, compound $\mathbf{9}$, was also isolated.

Scheme 3. Epoxidation of compound 7

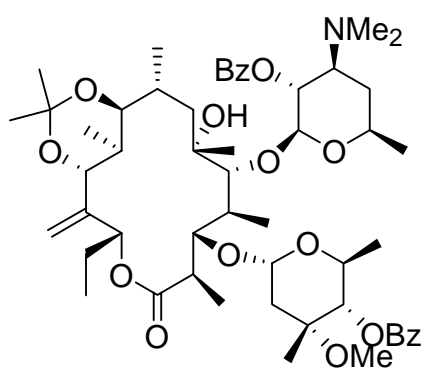

3

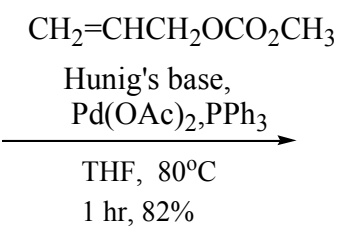

$1 \mathrm{hr}, 82 \%$

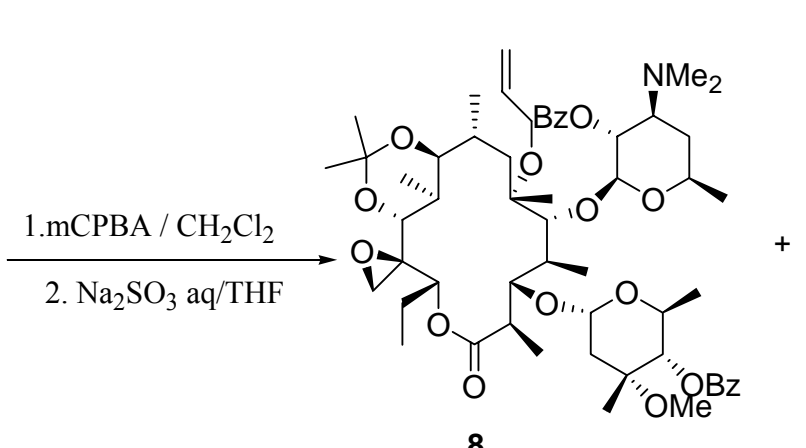

8

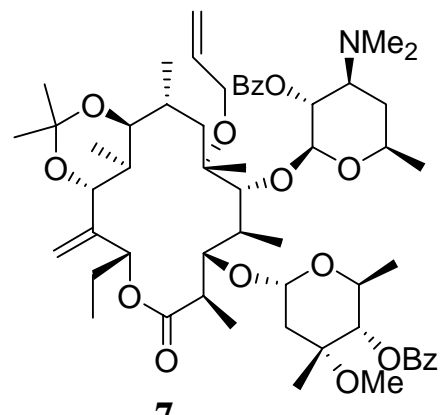

7

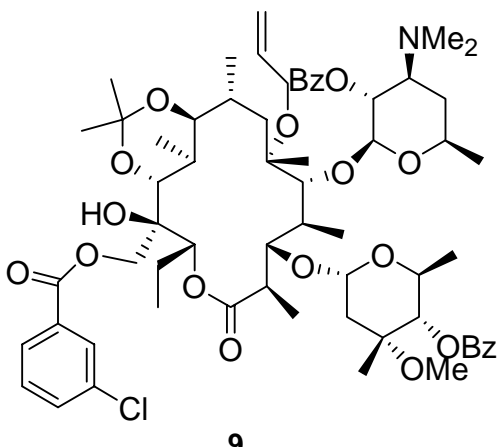

The epoxidation of olefins by peroxy acids is a widely used reaction for synthetic purposes and mechanistic studies [11]. The bimolecularity and stereospecificity of the process have been generally rationalized by the Bartlett "butterfly" transition structure [12-13] as shown in structure 10 (Figure 3). An alternative transition structure, which resembles a 1,3-dipolar cycloaddition, has been suggested and is shown in structure 11. The formation of compound $\mathbf{9}$ agrees with the latter. Since $m$-CPBA is a weak acid, it is difficult for it to attack the epoxide to form compound $\mathbf{9}$.

Figure 3. The mechanism of formation of compound 9

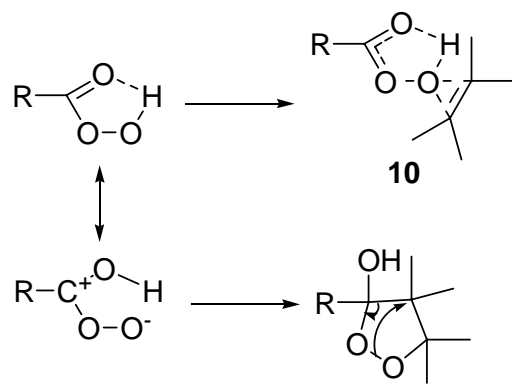




\section{Conclusions}

The C12-21 alkene is a reactive site of erythromycin A derivatives, which can be oxidized to an epoxide by organic peroxyacids, even in the presence of a 6-O-allyl moiety in the same molecule. Furthermore, it can react with diazomethane to give a [3+2] cycloaddition product, a C-12- $\Delta^{1}-$ pyrazoline derivative. These compounds, with their versatile epoxide and pyrazoline moieties can be used to synthesize potentially useful new erythromycin A derivatives.

\section{Acknowledgements}

The author is grateful to Professor Henry N. C. Wong and Professor Thomas C. W. Mak of the Department of Chemistry, The Chinese University of Hong Kong for experimental advice and for performing the X-ray crystallographic analyses, respectively, and to Dr. Chi-Keung Lam of the Department of Chemistry, Sun Yat-Sen University for the crystallographic data analyses. The work described in this project is supported partially by Chiron Corporation, Emeryville, California 946082916, U.S.A. and the Jinan University Foundation.

\section{Experimental Section}

\section{General}

All reagents and solvents were reagent grade. Further purification and drying by standard methods were employed when necessary. Erythromycin A and its derivatives were pre-dried azeotropically from benzene. THF was distilled from sodium benzophenone ketyl. $\mathrm{CH}_{2} \mathrm{Cl}_{2}$ and EtOAc were distilled from $\mathrm{CaH}_{2}$. DMF, DMSO and HMPA were redistilled and stored in screw-cap vials with molecular sieve (4A). All organic solvents were evaporated under reduced pressure with a rotary evaporator. The plates used for thin-layer chromatography (TLC) were E. Merck silica gel 60F 254 (0.1 mm thickness) precoated on aluminum plates, and they were visualized under both long $(365 \mathrm{~nm})$ and short $(254 \mathrm{~nm})$ UV light. Compounds on TLC plates were visualized with a spray of 5\% dodocamolybdophosphoric acid in ethanol and subsequent heating. Column chromatography was performed using E. Merck silica gel (230-400 mesh). Melting points were measured using Electrothermal IA9100 digital melting point apparatus and are uncorrected. NMR spectra were recorded at $300 \mathrm{~K}$ in deuterated chloroform solution on a Bruker DPX-300 spectrometer (operating at $300.13 \mathrm{MHz}$ for ${ }^{1} \mathrm{H}$ and $75.47 \mathrm{MHz}$ for ${ }^{13} \mathrm{C}$ ). Chemical shifts are reported as parts per million (ppm) in the $\delta$ scale relative to the resonance of $\mathrm{CDCl}_{3}$ (7.26 ppm in the ${ }^{1} \mathrm{H}, 77.00 \mathrm{ppm}$ for the central line of the triplet in the ${ }^{13} \mathrm{C}$ modes, respectively). Coupling constants $(J)$ are reported in Hz. Splitting patterns are described by using the following abbreviations: s, singlet; d, doublet; t, triplet; q, quartet; m, multiplet. ${ }^{1} \mathrm{H}-\mathrm{NMR}$ data is reported in this order: chemical shift; multiplicity; coupling constant(s), number of protons. Mass spectra (ERMS and HRMS) were obtained with a Thermo Finnigan MAT95XL spectrometer or a API 2000 LC/MS/MS system. Relevant data are tabulated as $\mathrm{m} / \mathrm{z}$. Elemental analyses were performed at the Shanghai Institute of Organic Chemistry, Chinese Academy of Sciences, China. 
(9S)-9,11-O-Isopropylidene-2',4"-O-bis(benzoyl)- (12R)-12,21-epoxy-9-dihydroerythromycin A (5).

To a solution of compound $3(6.0 \mathrm{~g}, 6.2 \mathrm{mmol})$ in dichloromethane $(60 \mathrm{~mL})$ at $0^{\circ} \mathrm{C}$ was added m-CPBA (5.4 g, $31 \mathrm{mmol}, 5$ equiv). The mixture was stirred at r.t. for 19 hrs. The reaction was quenched by adding cyclohexene $(2.6 \mathrm{~mL})$ and stirred for another $4 \mathrm{hrs}$. The reaction was worked up by pouring into sat. aq. $\mathrm{NaHCO}_{3}(100 \mathrm{~mL})$. The organic layer was separated and the aqueous layer was extracted with dichloromethane $(60 \mathrm{~mL} \times 2)$. The combined organic layer was washed with brine $(100$ $\mathrm{mL}$ ), dried over $\mathrm{Na}_{2} \mathrm{SO}_{4}$ and concentrated in vacuo to give a residue 4, which was used in the next step without further purification. The crude material 4 was dissolved in THF (90 mL). To this was added a solution of $\mathrm{Na}_{2} \mathrm{SO}_{3}(10.8 \mathrm{~g})$ in water $(45 \mathrm{~mL})$. The mixture was stirred for $20 \mathrm{hrs}$. and then worked up by separating the organic layer, extracting the aqueous layer with EtOAc $(50 \mathrm{~mL})$ and combining the organic portions, which were washed with brine $(100 \mathrm{~mL})$, dried over $\mathrm{Na}_{2} \mathrm{SO}_{4}$ and concentrated in vacuo. The crude material was purified with a silica gel column (200 g, eluted with 4:1 hexanesacetone containing $0.5 \%$ triethylamine) to give 5 (4.2 g, 69\% from 3); mp: $126-127^{\circ} \mathrm{C}$; IR ( $\left.\mathrm{KBr}\right) \mathrm{cm}^{-1}$ $3528(\mathrm{w}), 1725$ (s), $1268(\mathrm{~s}) ;{ }^{1} \mathrm{H}-\mathrm{NMR}\left(\mathrm{CDCl}_{3}\right) \delta 0.68$ (d, J=7.2 Hz, 3H), 0.80 (t, J=7.2 Hz, 3H), 0.91 $(\mathrm{d}, J=5.7 \mathrm{~Hz}, 3 \mathrm{H}), 1.00(\mathrm{~m}, 6 \mathrm{H}), 1.09(\mathrm{~d}, J=7.2 \mathrm{~Hz}, 3 \mathrm{H}), 1.17(\mathrm{~m}, 10 \mathrm{H}), 1.30(2 \mathrm{~s}, 6 \mathrm{H}), 1.4(\mathrm{~m}, 1 \mathrm{H})$, 1.5-1.8 (m, 5H), $2.0(\mathrm{~m}, 2 \mathrm{H}), 2.33(\mathrm{~s}, 6 \mathrm{H}), 2.35-2.60(\mathrm{~m}, 2 \mathrm{H}), 2.63(\mathrm{~m}, 1 \mathrm{H}), 2.99(\mathrm{~m}, 2 \mathrm{H}), 3.34(\mathrm{~m}$, $1 \mathrm{H}), 3.52(\mathrm{~m}, 1 \mathrm{H}), 3.56(\mathrm{~s}, 3 \mathrm{H}), 3.92(\mathrm{~s}, 2 \mathrm{H}), 4.06(\mathrm{~s}, 1 \mathrm{H}), 4.06(\mathrm{~s}, 1 \mathrm{H}), 4.5(\mathrm{~m}, 1 \mathrm{H}), 4.70(\mathrm{~d}, J=4.5$ $\mathrm{Hz}, 1 \mathrm{H}), 4.85(\mathrm{~m}, 1 \mathrm{H}), 4.92(\mathrm{~d}, J=9.6 \mathrm{~Hz}, 1 \mathrm{H}), 5.03(\mathrm{~d}, J=9.6 \mathrm{~Hz}, 1 \mathrm{H}), 5.20(\mathrm{~m}, 1 \mathrm{H}), 7.41(\mathrm{~m}, 4 \mathrm{H})$, $7.54(\mathrm{~m}, 2 \mathrm{H}), 8.00(\mathrm{~m}, 4 \mathrm{H}) ;{ }^{13} \mathrm{C}-\mathrm{NMR}\left(\mathrm{CDCl}_{3}\right) \delta 9.5,11.1,12.5,16.0,17.6,18.0,20.9,21.2,21.7$, 23.6, 27.5, 31.9, 32.4, 40.8, 42.9, 43.2, 49.3, 59.2, 63.4, 63.7, 65.3, 68.2, 72.1, 73.3, 73.8, 76.5, 78.7, $79.8,85.3,95.2,99.7,101.1,128.1,128.3,129.4,129.9,130.6,132.6,133.2,165.4,166.0,175.2 ; \mathrm{MS}$ m/z $982\left(\mathrm{MH}^{+}\right)$; Anal. Calcd for $\mathrm{C}_{54} \mathrm{H}_{79} \mathrm{NO}_{15}: \mathrm{C}, 66.03 ; \mathrm{H}, 8.11 ; \mathrm{N}, 1.43$. Found: $\mathrm{C}, 65.45 ; \mathrm{H}, 8.06$; $\mathrm{N}$, 1.39 .

(9S)-9,11-O-Isopropylidene-2',4"-O-bis(benzoyl)-12-(41'-pyrazoline)-12-dehydroxyl-21-demethyl-9dihydroerythromycin A (6).

To a solution of compound $3(1.0 \mathrm{~g}, 1 \mathrm{mmol})$ in ether $(10 \mathrm{~mL})$ cooled with ice-salt bath, was added diazomethane $(\sim 10 \mathrm{mmol})$, freshly prepared by reacting $\mathrm{CH}_{3} \mathrm{~N}(\mathrm{NO}) \mathrm{CONH}_{2}(3.0 \mathrm{~g}, 20 \mathrm{mmol})$ with $\mathrm{KOH}(2.0 \mathrm{~g}, 36 \mathrm{mmol})$ in $\mathrm{H}_{2} \mathrm{O}(3 \mathrm{~mL})$ and ether $(20 \mathrm{~mL})$ solution and silica gel $(100 \mathrm{mg})$. The mixture was stirred at r.t. for $44 \mathrm{hr}$. The ether was removed. To the residue was added EtOAc $(50 \mathrm{~mL})$ and the mixture was filtered. The filtrate was concentrated and purified on a silica gel column (50 g, elution with 5:1 hexanes-ethyl acetate) to give compound 6 (0.13 g, 13\%). Starting material 3 (0.64 g) was also recovered, so the yield based on reacted substrate was $80 \%$. IR $(\mathrm{KBr}) \mathrm{cm}^{-1} 3528(\mathrm{w}), 1727(\mathrm{~s})$, $1268(\mathrm{~s}) ;{ }^{1} \mathrm{H}-\mathrm{NMR}\left(\mathrm{CDCl}_{3}\right) \delta 0.71(\mathrm{~d}, J=7.2 \mathrm{~Hz}, 3 \mathrm{H}), 0.80(\mathrm{~m}, 3 \mathrm{H}), 0.92-1.02(\mathrm{~m}, 9 \mathrm{H}), 1.11-1.27(\mathrm{~m}$, 23H), 1.30-1.50 (m, 4H), 1.74-1.79 (m, 3H), 2.05 (br s, 2H), 2.35 (s, 6H, N(CH $\left.)_{2}\right), 2.39$ (ss, 1H), 2.48 $(\mathrm{m}, 1 \mathrm{H}), 3.02(\mathrm{~m}, 1 \mathrm{H}), 3.34(\mathrm{~m}, 1 \mathrm{H}), 3.56\left(\mathrm{~s}, 3 \mathrm{H},-\mathrm{O}-\mathrm{CH}_{3}\right), 3.92(\mathrm{~m}, 1 \mathrm{H}), 4.02(\mathrm{~m}, 1 \mathrm{H}), 4.29(\mathrm{~m}, 2 \mathrm{H})$, $4.45-4.53(\mathrm{~m}, 3 \mathrm{H}), 4.75(\mathrm{~s}, 1 \mathrm{H}), 4.92(\mathrm{~d}, J=9.9 \mathrm{~Hz}, 1 \mathrm{H}), 5.02(\mathrm{~d}, J=7.5,1 \mathrm{H}), 5.20(\mathrm{~m}, 1 \mathrm{H}), 7.44(\mathrm{~m}, 4 \mathrm{H})$, $7.55(\mathrm{~m}, 2 \mathrm{H}), 7.99(\mathrm{~m}, 4 \mathrm{H}) ;{ }^{13} \mathrm{C}-\mathrm{NMR}\left(\mathrm{CDCl}_{3}\right) \delta 9.9,11.1,12.5,14.0,16.5,17.8,18.1,20.7,21.0,21.2$, 23.7, 24.4, 27.7, 29.2, 29.6, 31.7, 32.1, 32.5, 35.2, 40.9, 43.1, 49.4, 63.5, 63.7, 68.2, 68.7, 72.1, 73.3, $73.9,78.9,79.0,80.1,85.4,95.6,99.3,99.9,128.2,128.3,129.6,130.0,130.7,132.6,133.2,165.5$, 
166.0, 174.8; MS m/z $1008\left(\mathrm{MH}^{+}\right)$, HRMS (FAB) Calcd for $\mathrm{C}_{55} \mathrm{H}_{82} \mathrm{~N}_{3} \mathrm{O}_{14}\left(\mathrm{MH}^{+}\right)$: 1008.5791. Found: 1008.5813.

(9S)-9,11-O-Isopropylidene-6-O-allyl-2',4"-O-bis(benzoyl)-12,21-anhydro-9-dihydroerythromycin A (7).

To a solution of compound $3(0.50 \mathrm{~g}, 0.52 \mathrm{mmol})$ in anhydrous THF $(5 \mathrm{~mL})$ was added allyl methyl carbonate $(0.12 \mathrm{~mL}, 1.04 \mathrm{mmol})$ and Hünig's base $(0.18 \mathrm{~mL}, 1.04 \mathrm{mmol})$. The mixture was degassed with nitrogen for $30 \mathrm{~min}$. This solution was transferred to a mixture of palladium (II) acetate (18 mg, $15 \mathrm{~mol} \%$ ) and triphenylphosphine (42 mg, $25 \mathrm{~mol} \%$ ). The reaction mixture was heated to $80^{\circ} \mathrm{C}$ for $1 \mathrm{hr}$. Worked up by diluting with EtOAc $(20 \mathrm{~mL})$, washed with sat. aq. $\mathrm{NaHCO}_{3}(20 \mathrm{~mL})$, dried over $\mathrm{Na}_{2} \mathrm{SO}_{4}$ and concentrated in vacuo. The residue was purified by a silica gel column (100 g, hexanes-acetone $4: 1$ with $0.5 \%$ TEA) to give 6-O-allyl product 7 (430 mg, 82\%); IR (KBr) cm ${ }^{-1} 1726$ (s), 1268(s); ${ }^{1} \mathrm{H}-\mathrm{NMR}\left(\mathrm{CDCl}_{3}\right) \delta 0.66(\mathrm{~d}, J=6.6 \mathrm{~Hz}, 3 \mathrm{H}), 0.76(\mathrm{~d}, J=6.9 \mathrm{~Hz}, 3 \mathrm{H}), 0.88(\mathrm{~m}, 1 \mathrm{H}), 0.99$ $(\mathrm{d}, J=6.9 \mathrm{~Hz}, 3 \mathrm{H}), 1.00-1.25(\mathrm{~m}, 15 \mathrm{H}), 1.29(\mathrm{~s}, 3 \mathrm{H}), 1.34(\mathrm{~s}, 3 \mathrm{H}), 1.41(\mathrm{~m}, 2 \mathrm{H}), 1.61(\mathrm{~m}, 5 \mathrm{H}), 1.8(\mathrm{~m}$, 2H), 1.9-2.1 (m, 3H), $2.31\left(\mathrm{~s}, 6 \mathrm{H}, \mathrm{N}\left(\mathrm{CH}_{3}\right)_{2}\right), 2.36(\mathrm{~d}, J=7.5 \mathrm{~Hz}, 1 \mathrm{H}), 2.38(\mathrm{~s}, 0.5 \mathrm{H}), 2.85(\mathrm{~m}, 1 \mathrm{H}), 2.95$ (m, 1H), 3.40 (s, 3H, -O-CH $), 3.55(\mathrm{~d}, \mathrm{~J}=3.6 \mathrm{~Hz}, 1 \mathrm{H}), 3.77(\mathrm{~s}, 1 \mathrm{H}), 3.70-3.85(\mathrm{~m}, 2 \mathrm{H}), 3.95(\mathrm{~s}, 1 \mathrm{H})$, $4.50(\mathrm{~m}, 2 \mathrm{H}), 4.54(\mathrm{~d}, J=6 \mathrm{~Hz}, 2 \mathrm{H}), 4.73(\mathrm{~d}, J=4.5 \mathrm{~Hz}, 2 \mathrm{H}), 4.88(\mathrm{~m}, 2 \mathrm{H}), 5.00(\mathrm{~s}, 1 \mathrm{H}), 5.08(\mathrm{~s}, 1 \mathrm{H})$, 5.10-5.35 (m, 3H), $5.65(\mathrm{~m}, 1 \mathrm{H}), 5.80-6.00(\mathrm{~m}, 2 \mathrm{H}), 7.46(\mathrm{~m}, 4 \mathrm{H}), 7.58(\mathrm{~m}, 2 \mathrm{H}), 8.03(\mathrm{~m}, 4 \mathrm{H}) ;{ }^{13} \mathrm{C}-$ NMR $\left(\mathrm{CDCl}_{3}\right) \delta 10.7,11.2,13.2,17.2,17.5,18.4,20.9,21.3,22.4,23.7,25.2,31.0,31.9,37.5,40.8$, $41.3,49.5,63.1,63.3,65.3,68.6,68.8,72.1,73.1,74.5,78.2,78.9,80.1,82.8,95.3,99.9,100.5,112.6$, $118.6,124.1,128.1,128.3,129.6,129.8,131.2,132.1,132.5,133.2,143.5,165.4,166.3,175.2$; MS $\mathrm{m} / \mathrm{z}$ 1006( $\left.\mathrm{MH}^{+}\right)$; Anal. Calcd for $\mathrm{C}_{57} \mathrm{H}_{83} \mathrm{NO}_{14}: \mathrm{C}, 68.03 ; \mathrm{H}, 8.31 ; \mathrm{N}, 1.39$. Found: $\mathrm{C}, 67.90 ; \mathrm{H}, 8.35 ; \mathrm{N}$, 1.44 .

(9S)-9,11-O-Isopropylidene-6-O-allyl-2',4"-O-bis(benzoyl)-12,21-epoxy-9-dihydroerythromycin A (8) and (9S)-9,11-O-isopropylidene-6-O-allyl-2',4"-O-bis(benzoyl)-12-hydroxy-21-(m-chlorobenzoyloxy)9-dihydroerythromycin A (9).

To a solution of compound $7(0.19 \mathrm{~g}, 0.19 \mathrm{mmol})$ in dichloromethane $(5 \mathrm{~mL})$ at $0^{\circ} \mathrm{C}$ was added m-CPBA (96 mg, $0.39 \mathrm{mmol}, 2.05$ equiv). The mixture was stirred at r.t. for $13 \mathrm{hrs}$. The reaction was worked up by pouring into sat. aq. $\mathrm{NaHCO}_{3}(15 \mathrm{~mL})$. The organic layer was separated and the aqueous layer was extracted with dichloromethane $(15 \mathrm{~mL} \times 2)$. The combined organic layers were washed with brine $(15 \mathrm{~mL})$, dried over $\mathrm{Na}_{2} \mathrm{SO}_{4}$ and concentrated in vacuo to give a residue which was used without further purification. The crude material was dissolved in THF $(3 \mathrm{~mL})$ and to this was added a solution of $\mathrm{Na}_{2} \mathrm{SO}_{3}(0.36 \mathrm{~g})$ in water $(1.5 \mathrm{~mL})$. The mixture was stirred for $18 \mathrm{~h}$, then worked up by separating the organic layer and extracting the aqueous layer was with EtOAc $(5 \mathrm{~mL})$. The organic portions were combined, washed with brine $(5 \mathrm{~mL})$, dried over $\mathrm{Na}_{2} \mathrm{SO}_{4}$ and concentrated in vacuo. The crude material was purified with a silica gel column ( $50 \mathrm{~g}$, hexanes-acetone $4: 1$ with $0.5 \%$ TEA) to give 8 (130 mg, 67\% from 7) and 9 (20 mg, 8.9\%). Compound 8: IR (KBr) cm ${ }^{-1} 1727$ (s), 1269 (s); ${ }^{1} \mathrm{H}-\mathrm{NMR}$ $\left(\mathrm{CDCl}_{3}\right) \delta 0.71(\mathrm{~m}, 3 \mathrm{H}), 0.80(\mathrm{~m}, 3 \mathrm{H}), 0.96(\mathrm{~m}, 5 \mathrm{H}), 1.04(\mathrm{~d}, J=6 \mathrm{~Hz}, 3 \mathrm{H}), 1.10-1.26(\mathrm{~m}, 15 \mathrm{H}), 1.27$ (s, 3H), 1.32 (s, 3H), 1.39 (s, 3H), 1.50-2.00 (m, 7H), 2.30 (s, 6H, NMe $), 2.4$ (ss, 1H), 2.80 (m, 1H), 
$2.95(\mathrm{~m}, 1 \mathrm{H}), 3.41(\mathrm{~s}, 3 \mathrm{H}, \mathrm{O}-\mathrm{Me}), 3.51(\mathrm{~m}, 2 \mathrm{H}), 3.65(\mathrm{~s}, 1 \mathrm{H}), 3.80-4.00(\mathrm{~m}, 2 \mathrm{H}), 4.2(\mathrm{~m}, 1 \mathrm{H}), 4.4(\mathrm{~m}$, $1 \mathrm{H}), 4.52(\mathrm{~d}, J=5.7 \mathrm{~Hz}, 2 \mathrm{H}), 4.73(\mathrm{~m}, 1 \mathrm{H}), 4.88(\mathrm{~m}, 2 \mathrm{H}), 5.05-5.25(\mathrm{~m}, 4 \mathrm{H}), 5.90(\mathrm{~m}, 1 \mathrm{H}), 7.34-7.56$ $(\mathrm{m}, 6 \mathrm{H}), 7.99(\mathrm{~m}, 4 \mathrm{H}) ;{ }^{13} \mathrm{C}-\mathrm{NMR}\left(\mathrm{CDCl}_{3}\right) \delta 10.3,11.6,13.5,17.0,17.5,17.7,20.9,21.3,21.8,23.7$, 25.3, 32.0, 35.5, 40.8, 41.0, 41.4, 49.5, 57.3, 57.7, 63.1, 65.3, 69.5, 72.0, 73.1, 74.5, 78.2, 78.8, 83.0, $95.3,100.5,101.5,110.4,118.5,128.1,128.3,129.6,129.8,130.5,132.0,132.5,133.2,143.2,143.3$, 165.3, 166.2, 175.0; MS m/z $1022\left(\mathrm{MH}^{+}\right)$, HRMS (FAB) Calcd for $\mathrm{C}_{57} \mathrm{H}_{84} \mathrm{NO}_{15}\left(\mathrm{MH}^{+}\right)$: 1022.5835 . Found: 1022.5841. Compound 9: IR (KBr) cm ${ }^{-1} 1727(\mathrm{~s}), 1267(\mathrm{~s}) ;{ }^{1} \mathrm{H}-\mathrm{NMR}\left(\mathrm{CDCl}_{3}\right) \delta 0.71(\mathrm{~m}, 5 \mathrm{H})$, $0.83(\mathrm{~m}, 2 \mathrm{H}), 0.96(\mathrm{~d}, \mathrm{~J}=6.9 \mathrm{~Hz}, 3 \mathrm{H}), 1.04(\mathrm{~d}, \mathrm{~J}=5.7 \mathrm{~Hz}, 3 \mathrm{H}), 1.10(\mathrm{~m}, 12 \mathrm{H}), 1.20(\mathrm{~m}, 1 \mathrm{H}), 1.28(\mathrm{~s}, 3 \mathrm{H})$, $1.32(\mathrm{~s}, 3 \mathrm{H}), 1.38(\mathrm{~s}, 1 \mathrm{H}), 1.44(\mathrm{~d}, \mathrm{~J}=6 \mathrm{~Hz}, 3 \mathrm{H}), 1.60-1.80(\mathrm{~m}, 3 \mathrm{H}), 1.90(\mathrm{~m}, 1 \mathrm{H}), 2.0(\mathrm{~m}, 2 \mathrm{H}), 2.29(\mathrm{~s}$, 6H, $\left.\mathrm{NMe}_{2}\right), 2.39$ (d, J=13.2 Hz, 1H), $2.75(\mathrm{~m}, 1 \mathrm{H}), 2.95(\mathrm{~m}, 1 \mathrm{H}), 3.41$ (s, 3H, O-Me), $3.42(\mathrm{~m}, 1 \mathrm{H})$, $3.49(\mathrm{~s}, 1 \mathrm{H}), 3.79(\mathrm{~m}, 2 \mathrm{H}), 3.90(\mathrm{~m}, 1 \mathrm{H}), 4.19(\mathrm{~m}, 1 \mathrm{H}), 4.42(\mathrm{~m}, 2 \mathrm{H}), 4.52(\mathrm{~d}, J=5.7 \mathrm{~Hz}, 2 \mathrm{H}), 4.73(\mathrm{~m}$, $1 \mathrm{H}), 4.87(\mathrm{dd}, J=9.9,9.6 \mathrm{~Hz}, 2 \mathrm{H}), 5.10(\mathrm{~m}, 1 \mathrm{H}), 5.20(\mathrm{~d}, J=10.5,1 \mathrm{H}), 5.28(\mathrm{~d} J=15.6 \mathrm{~Hz}, 1 \mathrm{H}), 5.58(\mathrm{~d}$, $J=10.5 \mathrm{~Hz}, 1 \mathrm{H}), 5.90(\mathrm{~m}, 2 \mathrm{H}), 7.30-7.60(\mathrm{~m}, 8 \mathrm{H}), 7.87(\mathrm{~m}, 1 \mathrm{H}), 7.90-8.05(\mathrm{~m}, 5 \mathrm{H}) ;{ }^{13} \mathrm{C}-\mathrm{NMR}\left(\mathrm{CDCl}_{3}\right) \delta$ $10.4,11.6,13.6,17.4,17.6,20.9,21.2,21.9,24.1,25.6,31.2,31.9,34.6,35.5,38.0,40.6,40.8,41.5$, $45.9,49.5,59.1,63.1,63.2,65.3,68.5,68.8,70.1,72.1,73.2,74.5,78.7,78.9,80.2,82.8,95.3,99.7$, $100.5,118.6,126.1,127.6,128.1,128.3,129.5,129.7,130.5,131.9,132.1,132.5,132.7,133.2,134.3$, 140.5, 164.9, 165.4, 166.2, 175.1; MS m/z $1178\left(\mathrm{MH}^{+}\right)$, HRMS (FAB) Calcd for $\mathrm{C}_{64} \mathrm{H}_{88} \mathrm{Cl}_{1} \mathrm{~N}_{1} \mathrm{O}_{17}$ $\left(\mathrm{MH}^{+}\right): 1178.5814$. Found: 1178.5841 .

Single crystal X-ray structure analyses of compound 5 [14].

The structure of 5 was determined by X-ray crystallography of a crystal that measured $1.522 \times$ $1.319 \times 0.743 \mathrm{~mm}$. Diffraction measurements were made on a Bruker SMART CCD diffractometer with graphite monochromated Mo K $\alpha$ radiation. Preliminary indications of the unit cell based on randomly selected reflections revealed orthorhombic symmetry with the following lattice parameters: $a=1$ 1.4313(9) $\AA, b=16.2380(13) \AA, c=30.192(3) \AA$, with $\alpha=\beta=\gamma=90.0^{\circ}$. The space group was $\mathrm{P} 2{ }_{1} 2_{1} 2_{1}, Z=4$ with one molecule of composition $\mathrm{C}_{54} \mathrm{H}_{79} \mathrm{NO}_{15} \cdot 1 / 4 \mathrm{H}_{2} \mathrm{O}$. The calculated density was $1.164 \mathrm{~g} / \mathrm{cm}^{3}$. There were 30258 reflections collected with $\theta$ rang from 1.42 to $25.00^{\circ}$, of those reflections 9866 with $\mathrm{I}>2 \sigma(\mathrm{I})$ were adjudged observed. The structure was solved by SHELXS-97.

\section{References and Notes}

1. Dax, S.L. Antibacterial Chemotherapeutic Agents; Blackie Academic \& Professional: London, 1997; pp. 257-264.

2. Lartey, P. A.; Faghih, R. Recent progress in the chemical modification of erythromycin. In Recent Progress in the Chemical Synthesis of Antibiotics and Related Microbial Products; Lukacs, G., Ed.; Springer: Berlin, 1993; Vol. 2, pp. 121-140.

3. Hauske, J. R.; Guardliana, M.; Kostek, G.; Schulte, G. Aglycon modifications of erythromycin A: regiospecific and stereospecific elaboration of the C-12 position. J. Org. Chem. 1987, 52, 46224625. 
4. Lartey, P. A.; DeNinno, S. L.; Faghih, R.; Hardy, D. J.; Clement, J. J.; Plattner, J. J. Synthesis and activity of C-21 alkylamino derivatives of (9R)-erythromycylamine. J. Antibiot. 1992, 45, 380385 .

5. Chen, W. M.; Wong, H. N. C.; Chu, D. T. W.; Lin, X. D. Synthetic studies of erythromycin derivatives: 6-O-methylation of (9S)-12,21-anhydro-9-dihydroerythromycin A derivatives. Tetrahedron, 2003, 59, 7033-7045.

6. Maas, G. In Synthetic Applications of 1,3-Dipolar Cycloaddition Chemistry toward Heterocycles and Natural Products, Padwa, A.; Pearson, W. H., Eds.; John Wiley \& Sons, Inc.: New York, 2002; pp. 541-609.

7. Yamashita, Y.; Kobayashi, S. Zirconium-catalyzed enantioselective [3+2] cycloaddition of hydrazones to olefins leading to optically active pyrazolidine, pyrazoline, and 1,3-diamine derivatives. J. Am. Chem. Soc. 2004, 126, 11279-11282.

8. Berghot, M.A.; Moawad, E.B. Convergent synthesis and antibacterial activity of pyrazole and pyrazoline derivatives of diazepam. Eur. J. Pharm. Sci. 2003, 20, 173-179

9. Gokhan, N.; Yesilada, A.; Ucar, G.; Erol, K.; Bilgin, A. A. 1-N-substituted thiocarbamoyl-3phenyl-5-thienyl-2-pyrazolines: synthesis and evaluation as MAO inhibitors. Arch. Pharm. (Weinheim) 2003, 336, 362-371.

10. Deardorff, D. R.; Linde, R. G.; Martin, A. M.; Shulman, M. J. Enantioselective preparation of functionalized cyclopentanoids via a common chiral ( $\pi$-allyl)palladium complex. J. Org. Chem. 1989, 54, 2759-2762.

11. Woods, K. W.; Beak, P. The endocyclic restriction test: an experimental evalution of the geometry at oxygen in the transition structure for epoxidation of an alkene by a peroxy acid. $J$. Am. Chem. Soc. 1991, 113, 6281-6283.

12. Bartlett, Singleton, D.A.; Merrigan, S.R.; Liu, J.; Houk, K.K. Experimental geometry of the epoxidation transition state. J. Am. Chem. Soc. 1997, 119, 3385-3386

13. Kwart, H.; Hoffman, D.M. Observations regarding the mechanism of olefin epoxidation with per acids J. Org. Chem. 1966, 31, 419-425.

14. CCDC 289455 contains the supplementary crystallographic data for this paper. These data can be obtained free of charge from The Cambridge Crystallographic Data Centre via www.ccdc.cam.ac.uk/data_request/cif.

Sample availability: Contact the author.

(C) 2006 by MDPI (http://www.mdpi.org). Reproduction is permitted for noncommercial purposes. 